\title{
KINERJA DOSEN DALAM PENGEMBANGAN BUDAYA AKADEMIK PADA SEKOLAH TINGGI ILMU TARBIYAH AL-HILAL SIGLI
}

\author{
Muhammad Iqbal1, Mustakim Sagita2 \\ Program Studi Pendidikan Bahasa Inggris \\ Fakultas Keguruan dan Ilmu Pendidikan \\ Universitas Jabal Ghafur
}

\begin{abstract}
ABSTRAK
Sekolah Tinggi Ilmu Tarbiyah Al-Hilal Sigli merupakan suatu lembaga pendidikan tinggi dan pusat kajian strategis ilmu pengetahuan Agama Islam, membutuhkan tenaga dosen yang memiliki kemampuan dan kinerja yang handal. Penelitian ini bertujuan untuk mengetahui kinerja dosen pada SekolahTinggillmuTarbiyah Al-Hilal Sigli. Penelitian ini menggunakan pendekatan deskriptif dan metode kualitatif dengan teknik pengumpulan data dokumentasi, observasi dan wawancara. Subjek penelitian para ketua sekolah tinggi, ketua prodi, dosen, kepala tata usaha, dan mahasiswa. Analisis data dilakukan dengan cara: reduksi data, penyajian data, dan penarikan kesimpulan. Penelitian ini menunjukkan bahwa: 1) Kinerja dosen dalam melaksanakan proses perkuliahan telah mengikuti prinsipprinsip pembelajaran, hal ini dilihat dari perencanaan, pelaksanaan dan evaluasi perkuliahan yang dilaksanakan oleh dosen. 2) Motivasi dosen dalam melaksanakan perkuliahan tercermin pada kemauan dan kesadaran dosen dalam melaksakan tugas-tugas yang diembankan kepadanya.
\end{abstract}

Kata kunci : Kinerja, Dosen, Akademik.

\section{Pendahuluan}

Pendidikan adalah suatu usaha sadar yang dilakukan orang dewasa untuk pendewasaan manusia yang dilakukan dalam proses kegiatan belajar mengajar, baik secara formal, informal maupun non formal. Pendidikan diharapkan bias menjawab segala tantangan zaman dan mampu membina generasi bangsa, sehingga menjadi manusia-manusia yang handal dan berkualitas, dengan karakteristik yang kuat, jati diri yang jelas serta mampu menghadapi masalah-masalah masa kini maupun dimasa yang akan datang.

PerguruanTinggiIslam Al-Hilal Sigli merupakan suatu lembaga pendidikan tinggi yang berusaha menjadi pusat kajian strategis ilmu pengetahuan Agama Islam, yaitu menyiapkan peserta didik menjadi anggota masyarakat yang memiliki kemampuan akademik yang profesional, mampu mengembangkan, menyebarluaskan dan mengamalkan ilmu pengetahuan agama Islam yang lebih baik. Untuk melaksanakan fungsi edukatif di perguruan tinggi, maka diperlukan tenaga pendidik yang memiliki kualifikasi pendidikan dan kompetensi yang baik." UndangUndang Sistem Pendidikan Nasional Nomor20/2003 Undang-undang Guru dan Dosen Nomor 14/2005" , mensyaratkan dosen perguruan tinggi minimal S2, dalam Undang-
Undang itu disebutkan, para pendidik jenjang pendidikan dasar dan menengah persyaratannya adalah minimal bergelar S1.Sementara, untuk mendidik di jenjang pendidikan akademis S1, maka sekurang-kurangnya bergelar strata dua (S2). Sedangkan bagi Pascasarjana persyaratan akademis tenaga pengajar adalah doktor (S3) dan professor.

Dosen harus mempunyai beberapa kualifikasi yang diperlukan bagi pelaksanaan profesinya, mengingat profesi dosen berbeda dengan profesi bidang yang lain. Selain ilmu pengetahuan dosen juga harus mampu menyampaikan ilmunya kepada mahasiswa. Dengan tenaga dosen yang mempunyai motivasi, berkompeten dan berkualitas akan memudahkan penyampaian ilmu pengetahuan dan teknologi sehingga apa yang disampaikan kepada mahasiswa dapat diterima dan dikembangkan sesuai dengan kemampuan mahasiswa dengan kajian bidang ilmu yang dipilihnya. Disamping itu dosen juga harus mempunyai komitmen yang tinggi yang ditunjukkan dengan kehadiran pada waktu kerja, juga mempunyai rasa tanggung jawab terhadap ilmu yang diberikan kepada mahasiswa.

Untuk melaksanakan tugas-tugas dosen secara efektif dan efisien para dosen dituntut harus memiliki kemampuan sesuai dengan 
bidang ilmu, sebagai tenaga akademisi bertanggungjawab terhadap kelangsungan pendidikan di perguruan tinggi, terutama terhadap proses pelaksanaan perkuliahan di Sekolah Tinggillmu Tarbiyah Al-Hilal Sigli dan dosen harus mampu melaksanakan tugasnya secara optimal Usman mengemukakan bahwa:

Kompetensi merupakan kemampuan yang mengambarkankelayakansetiapindividudalamme njalankantugas. Kompetensimerupakansuatu factor penting bagi individu, karena individu yang memiliki kompetensi akan mampu menampilkan kualitas dan produktivitas kerja dalam menjalankan suatu kegiatan. Kompetensi memperlihatkan perilaku yang memungkinkan mereka menjalankan tugas dengan cara yang paling diinginkan dan tidak sekedar menjalankan kegiatan bersifat rutinitas.

Kemampuan dan keterampilan yang dimiliki oleh tenaga dosen senantiasa perlu dikembangkan untuk meningkatkan peformance dosen di perguruan tinggi. Sehingga sumber daya manusia sebagai lulusan dari lembaga pendidikan tinggi yang akan terjun ke tengahtengah masyarakat akan mampu mengaplikasikan pengetahuan dan ketrampilannyadengan baik.

Dosen merupakan faktor penting dalam kaitan pelaksanaan pembinaan, pengembangan serta pengambilan keputusan dalam rangka mewujudkan visi, misi perguruan tinggi, disamping itu dapat digunakan sebagai penilaian kinerja secara terbuka yang mengacu pada tridharma perguruan tinggi yaitu pendidikan, penelitian dan pengabdian kepada masyarakat. DalamUndang-undang Nomor 12 tahun 2012 tentangPendidikan Tinggimenyebutkan bahwadosen merupakan tenaga pendidik profesional dan ilmuwan dengan tugas utama mentransformasikan, mengembangkan dan menyebarluaskan ilmu pengetahuan, teknologi dan melalui pendidikan, penelitian dan pengabdian kepada masyarakat.

Dosen senantiasa harus mengembangkan karya-karya inovatif dan inventif yang dapat dicapai melalui kegiatan penelitian maupun pengabdian kepada masyarakat. Sebagai konsekuensi profesi dosen dalam bidangnya, maka dosen harus mampu mencapai tingkatan kemampuan dalam bidang ilmunya yang menjadi tanggungjawabnya. Hal ini sesuai dengan pendapat Surya (Usman) mengatakan bahwa seoarang pendidik hendaknya memiliki kompetensi kinerja yang mantap yaitu seperangkat penguasaan kemampuan yang harus ada dalam dirinya agar dapat mewujudkan kinerja secara tepat dan efektif.

Kedisiplinan dan kesadaran dosen terhadap pelaksanaan tugas belum mencapai target yang ditentukan.Komitmen dosen dalam melaksanakan tugas sebagai tenaga pengajar belum tercermin pada prilakunya, beban tugas yang diberikan belum dapat dilaksanakan dengan penuh tanggungjawab. Oleh karena itu penilaian prestasi kerja seorang dosen dapat terlihat dari kedisiplinannya dalam melaksanakan tugas dan tanggung jawab terhadap pekerjaan yang telah dibebankan kepadanya sesuai dengan pembagian tugas mengajar pada setiap semester tahun akademik. Mutu kinerja dosen pada Sekolah Tinggi Ilmu Tarbiyah merupakan faktor yang harus ditingkatkan agar lembaga pendidikan bermutu dan berkembang.

Berdasarkan uraian di atas, untuk melihat lebih jauh tentang kinerja dosen, yang ditinjau dari kemampuan intelektual, motivasi, dan disiplin dalam melaksanakan tugas sebagai dosen. Penulis tertarik untuk melakukan penelitian dengan judul: "Kinerja Dosen dalam Pengembangan Budaya Akademik pada Sekolah Tinggi IlmuTarbiyah Al-Hilal Sigli”.

\section{Metode Penelitian}

Metode merupakan cara atau jalan yang ditempuh dalam melakukan sesuatu penelitian. Menurut Dawson, metode penelitian adalah alat yang digunakan untuk mengumpulkan data oleh seorang peneliti Dalam penelitian ini penulis menggunakan penelitian deskriptif. Deskriptif adalah memusatkan perhatian pada fenomena yang terjadi pada saat ini melalui upaya untuk membuat deskripsi fenomena yang di selidiki, dengan cara melukiskan dan mengklasifikasikan fakta atau karakteristik fenomena tersebut secara faktual dan cermat.

Berdasarkanpermasalahan yang diangkat oleh peneliti, makajenis penelitian yang digunakan dalam penelitian ini adalah penelitian deskriptif kualitatif yang bertujuan untuk melihat realita, keadaan dan fakta yang telah dan sedang berkembang. Dalam penelitian ini peneliti menghimpun data berupauraian yang memiliki nuansa deskripsi, mengenaiaktivitas, atau subjek yang akan diteliti, baik menyangkut persepsinya, dan hal-hal lain yang di dapati melalui wawancara, observasi dan dokumentasi. Pemilihan metode ini didasarkan atas pertimbangan bahwa yang hendak dicari adalah data yang akan memberikan gambaran dan 
melukiskan realita sosial yang konkrit tentang kinerja dosen pada Sekolah Tinggi Ilmu Tarbiyah Al-Hilal Sigli.

PengertianmetodekualitatifmenurutIskand ar "Metode kualitatif yaitu penelitian yang berpegangkepadaparadikmanaturalistikataufeno menalogi,

haliniterjadikarenapenelitianiniberusahamenjelas kanfonomen-fenomena yang telahberjalandansedangberjalan".

MenurutSugiyonopenelitiankualitatifadala hmetodepenelitian yang digunakanuntukmenelitipadakondisiobjek yang alamiah, dimanapenelitiadalahintrumenkuncidan data

dianalisissecarainduktifsertahasilpenelitianlebih menekankanmaknadaripadageneralisasi".

"dimana peneliti berusaha untuk menyelidiki dan mengungkapkan serta memaparkan data secara deskriptif sesuai dengan apa yang terjadi di lapangan. Selanjutnya penelitian kualitatif yang akan dilakukan memiliki ciri-ciri, sebagai mana dikemukakan oleh Iskandar: Karakteristik penelitian kualitatif adalah sebagai berikut: (1) peneliti terlibat langsung dalam proses penelitian, maksudnya data yang diteliti dan yang diperoleh akan dipaparkan sesuai dengan apa yang terjadi di lapangan. (2) data dianalisa secara induktif, (3) hasil penelitian bersifat deskriptif, sebab data yang diperoleh bukan angka-angka melainkan berupa kata-kata atau kalimat, (4) lebih mementingkan proses daripada hasil, (5) peneliti bertindak sebagai instrumen utama, maksudnya disamping sebagai pengumpul data dan penganalisa data.

Penelitian ini bertujuan untuk mengetahui kinerja dosen pada Sekolah Tinggi Ilmu Tarbiyah Al-Hilal Sigli yang meliputi, kemampuan, motivasi, komitmen dan disiplin dalam melaksanakan tugas sebagai tenaga edukatif. Hasil penelitian dipaparkan secara alami sesuai dengan apa yang terjadi di lapangan.Oleh karena itu, penelitian ini berbentuk penelitian deskriptif dengan memaparkan secara alami fakta yang ditemukan di lapangan tentang kinerja dosen pada Sekolah Tinggi Ilmu Tarbiyah Al-Hilal Sigli.

\section{HasilPenelitian}

Berdasarkanhasilpenelitian, paradosenmenginginkankinerjadoseniniterkaitde nganpengembangan.Sudahbarangtentupihaklem bagaharusbenar-

benarmewujudkankeinginantersebut, selainkarenasesuaidengankehendakdosen, jugarelevandenganteori-teori yang berkembangtentangkinerjapersonil yang bukansajauntukkepentinganmenilaisejauhmanak inerjadosentelahdiimplementasikansesuaistandar tetapihasilnyadipergunakanuntukpengembangan kariermelalui kegiatan: 1)kemampuandalampelaksanaanperkuliahan, seperti(a) perencanaan, (b) pelaksanaan, dan (c) evaluasi perkuliahan, 2) motivasi dosen dalam melaksanakan perkuliahan, kedisiplinandosendalam melaksanakan perkuliahan,

Komitmendantanggungjawabdosendalam melaksanakan perkuliahan.

\section{Kompetensi DosendalamMelaksanakan Perkuliahan}

a. Perencanaan Perkuliahan

Perencanaanperkuliahanmerupakanpersia pan yang harusdilakukan, danmerupakanlangkahawalyang harusdilakukanolehdosenadalahmempersiapkan perencanaan dengan penyusunan perencanaan perkuliahan yang sesuai dengan mata kuliah yang diasuhnya, yaitu dengan mempersiapkan berbagai perangkat perkulihan, seperti: penyusunan Satuan Acara Perkuliahan (SAP), persiapan materi perkuliahan, dan perencanan yang berkaitan dengan sistem penilaian perkuliahan. Perencanaan yang disusun oleh dosen memperhatikan tuntutan kompetensi dasar setiap mata kuliah, indikator pencapaian, skenario kegiatan perkuliahan, pengorganisasian bahan perkuliahan, media dan sumber perkuliahan, pengorganisasian waktu, serta merencanakan sistem penilaian perkuliahan, menelaahkurikulumdenganmenyusunsilabus,

halinidimaksudkanuntukmenjagakesesuaianantar akurikulum

yang

berlakudengankondisidanperkembanganmahasis wa.

Dosen mempersiapkan perencanaan dengan penyusunan perencanaan perkuliahan yang sesuai dengan mata kuliah yang diasuhnya, yaitu dengan mempersiapkan berbagai perangkat perkulihan, seperti: penyusunan Satuan Acara Perkuliahan (SAP), persiapan materi perkuliahan, dan perencanan yang berkaitan dengan sistem penilaian perkuliahan. Perencanaan yang disusun oleh dosen memperhatikan tuntutan kompetensi dasar setiap mata kuliah, indikator pencapaian, skenario kegiatan perkuliahan, pengorganisasian bahan perkuliahan, media dan sumber perkuliahan, 
pengorganisasian waktu, serta merencanakan sistem penilaian perkuliahan.

Sistem perkuliahan yang direncanakan oleh dosen sesuai dengan bidang mata kuliah yang diasuh dan sesuai dengan bidang keahliannya, sehingga dalam pembagian mata kuliah yang diberikan kepada dosen dengan memperhatian keahlian dan disiplin ilmu dosen tersebut. Karena tanpa adanya kesesuaian disiplin ilmu dan keahlian yang memadai oleh dosen maka tujuan pendidikan pendidikan di perguruan tinggi sulit untuk berhasil, sehingga untuk menjadi tenaga pendidik seperti dosen haruslah memiliki latarbelakang keilmuan yang baik melalui proses pendidikan yang relevan, sebagaimana yang telah dijelaskan oleh Usman.

Pelaksanaan perkuliahan merupakan tindak lanjut tugas dosen secara ril melakukan peranperan tugasnya. Pelaksanaan perkuliahan, apabila ditinjau dari tugas dosen, merupakan inti tugasnya, apa yang telah direncanakan dengan baik harus dapat diaplikasikan dengan baik dalam pelaksanaan tugas. Pelaksanaan perkuliahan mencakup penggunaan media, metode, bahan kuliah, mendemontrasikan penguasaan bahan kuliah, berkomunikasi, mendorong menggalakkan mahasiswa dan mengorganisir waktu, tempat dan materi kuliah. Paparan data yang telah diuraikan pada bahagian deskripsi data hasil penelitian, perencanaan perkuliahan merupakan upaya yang dilakukan dosen untuk merumuskan apa yang ingin dicapai dari perkuliahan yang akan dilaksanakan dan disesuaikan dengan visi, misi dan tujuan lembaga, sehingga perencanaan perkuliahan yang dilakukan oleh dosen disusun melalui pengembangan selabus pada tingkat jurusan yang dilakukan bersama-sama dosen satu jurusan maupun secara mandiri. Hal ini untuk menjamin mutu pendidikan yang baik, maka perencanaan program harus direncanakan sebelum perkuliahan tersebut dilaksanakan, karena perencanaan tersebut merupakan usaha bagaimana perkuliahan yang diinginkan dapat terlaksana sesuai dengan tujuan, sebagaimana yang telah dijelaskan oleh Usman.

Berdasarkan hasil penelitian, terungkap bahwa dosen menyusun rencana perkuliahan untuk merumuskan tujuan dan pelaksanaan perkuliahan. Perencanaan perkuliahan yang disusun oleh dosen berkaitan dengan sistem perkuliahan yang akan dilaksanakan oleh dosen tersebut nantinya. Untuk itu, langkah pertama yang harus dilakukan oleh dosen adalah menelaah kurikulum dengan menyusun silabus, hal ini dimaksudkan untuk menjaga kesesuaian antara kurikulum yang berlaku dengan kondisi, perkembangan ilmu pengetahuan dan teknologi saat ini, sebagaimana yang telah dijelaskan oleh E. Mulyasa.

Selanjutnya berkaitan dengan pengembangan silabus di Sekolah Tinggi Ilmu Tarbiyah Al-Hilal Sigli merupakan suatu keharusan, serta menyusun atau menyiapkan Satuan Acara Perkuliahan (SAP), hal ini berkaitan dengan kebijakan pimpinan Sekolah Tinggi Ilmu Tarbiyah Al-Hilal Sigli yang memperketat terhadap kesiapan dosen sebelum melaksanakan perkuliahan. Hal ini berkaitan juga dengan kebijakan Dikti melalui Badan Akreditasi Nasional Perguruan Tinggi (BAN PT) yang memiliki tugas untuk mengevaluasi dan memantau kegiatan dan pengelolaan program studi atau jurusan melalui pemberian akreditasi program studi. Salah satu yang komponen akreditasi yang dinilai oleh BAN PT adalah melihat dokumen persiapan perkuliahan yang dilaksanakan oleh dosen, baik dokumen silabus, SAP, contoh instrumen penilaian tiap semester, dan bahan kuliah yang digunakan oleh dosen.

Berdasarkan kebijakan Dikti dalam mengevaluasi pengelolaan dan pelaksanaan jurusan tersebut, maka kebijakan pimpinan pada Sekolah Tinggi Ilmu Tarbiyah mewajibkan bagi setiap dosen untuk mempersiapkan perencanaan yang berkaitan dengan perkuliahan dengan menyerahkan semua dokumen tersebut pada prodi masing-masing. Sehigga kebijakan ini selain bermanfaat terhadap jurusan dalam menyiapkan dokumen akreditasi prodi dan sangat bermanfaat juga terhadap dosen dalam melaksanakan perkuliahan.

Selanjutnya berdasarkan hasil penelitian juga terungkap bahwa, untuk memperlancar proses perkuliahan, dosen juga menyesuaikan rencana perkuliahan dengan karakteristik materi kuliah, melalui pemilihan strategi, model dan pendekatan perkuliahan yang tepat dan dapat membantu mahasiswa memahami materi perkuliahan dengan baik. Pemilihan strategi, model dan pendekatan perkuliahan yang direncanakan oleh dosen selalu diupayakan untuk dapat dilaksanakan sesuai perencanaan. Hal ini dilakukan untuk merencanakan perkuliahan yang efektif dan efesien, sehingga dosen harus kreatif dalam memilih strategi, model dan pendekatan perkuliahan. Hasil ini sesuai dengan teori yang dikemukakan oleh 
Ngainum Naim tentang proses pendekatan pembelajaran.

Sehingga perencanaan terhadap pemilihan strategi, model dan pendekatan perkuliahan yang tepat dapat membantu proses perkuliahan yang yang membantu mahasiswa menggali pengetahuan, keterampilan, dan sikap dalam mencapai tujuan pendidikan di perguruan tinggi sebagai suatu lembaga pendidikan.

\section{b. Kemampuan dalam Pelaksanaan Perkuliahan}

Berdasarkan hasil penelitian yang telah diuraikan pada bagian sebelumnya, terungkap bahwa dalam melaksanakan perkuliahan, dosen mengupayakan mahasiswa senantiasa dituntut aktif dalam setiap perkulihan. Pelaksanaan perkuliahan yang dilaksanakan oleh dosen di Sekolah Tinggi Ilmu Tarbiyah Al-Hilal Sigli meliputi kegiatan-kegiatan belajar diruang kuliah seperti penyampaian materi oleh dosen, diskusi, presentasi makalah, dan simulasi/praktek merupakan kegiatan yang terus diupayakan dalam upaya membantu mahasiswa memahami materi perkuliahan.

Berkaitan dengan penggunaan strategi, pendekatan dan metode dalam pelakasanaan perkuliahan yang dilaksanakan oleh dosen di Sekolah Tinggi Ilmu Tarbiyah Al-Hilal Sigli menunjukkan bahwa dosen berupaya dalam memberikan perkuliahan yang bervariasi, yang disesuaikan dengan tujuan perkuliahan, keadaan mahasiswa, keadaan ruang kuliah, sehingga ada keserasian dengan menggunakan strategi, pendekatan dan metode yang bervariasi dalam perkuliahan.

Pelaksanaan perkuliahan yang dilaksanakan dengan mempertimbangkan penggunaan metode dan pendekatan perkuliahan yang relevan dan bervariasi akan membantu dosen untuk melaksanakan perkuliahan yang efektif dan efesien, serta dapat mendorong dosen untuk merefleksi perkuliahan yang telah dilaksanakannya. Upaya tersebut, bila dilakukan secara berkesinambungan akan memberi dampak positif.

Berdasarkan hasil penelitiantergambarkan bahwa, seiring dengan perubahan paradigma perkuliahan di dunia pendidikan selama ini, mulai dari pendidikan dasar sampai pendidikan tinggi terjadi pergeseran paradigma dari perkuliahan yang berpusat pada dosen berubah menjadi berpusat pada mahasiswa. Perubahan paradigma ini di Sekolah Tinggi Ilmu Tarbiyah Al-Hilal Sigli, berpengaruh pada strategi atau pendekatan dosen pada mahasiswa dalam melaksanakan proses perkuliahan yang lebih menekankan aktivitas siswa melalui kegiatan yang mengaktifkan mahasiswa dalam belajar dan memahami memahami materi perkuliahan.

Selanjutnya terungkap pula bahwa, upaya merubah paradigma perkuliahan yang konvensional kepada perkuliahan yang inovatif oleh dosen di Sekolah Tinggi Ilmu Tarbiyah AlHilal Sigli, tidak serta-merta dapat dilaksanakan oleh semua dosen. Hal ini dapat dipahami bahwa sebagaian dosen sudah terbiasa melaksanakan perkuliahan dengan metode caramah dan menjadikan dosen satu-satunya sumber belajar bagi mahasiswa. Sehingga sulit bagi dosen yang sudah terbiasa melaksanakan perkuliahan dengan metode caramah sulit untuk merobah kepada melakukan inovasi perkuliahan.

Kemampuan dosen dalam pelaksanaan perkuliahan dapat dilihat melalui dosen dalam proses belajar mengajar dalam menggunakan metode, media dan bahan latihan yang sesuai dengan tujuan pengajaran, berkomunikasi dengan mahasiswa, menerapkan berbagai metodemengajar, mendorong dan menggalakkan keterlibatan mahasiswa dalam perkuliahan, mendemonstrasikan penguasaan suatu pelajaran dan relevansinya, sehingga mahasiswa aktif dalam belajar dan memberikan kesempatan kepada mahasiswa untuk menemukan dan merekonstruksi konsep-konsep atau pengetahuan secara aktif.

Selanjutnya kemampauan mengajar dosen juga merupakan kemampuan dalam mengorganisasikan waktu, mengevaluasi pencapaian mahasiswa dalam proses perkuliahan, yang pada dasarnya sudah diperoleh sejak dosen belajar pada lembaga pendidikan tenaga kependidikan. Namun, berdasarkan hasil penelitiaan juga tergambarkan bahwa ada pula sebagian kecil dosen yang kurang tertarik dalam mengembangkan dan menggunakan strategi, pendekatan dan metode perkuliahan, dengan kata lain dosen tersebut menggunakan model perkuliahan secara konvensional yaitu hanya menggunakan metode ceramah saja tanpa adanya inovasi dalam melaksanakan perkuliahan.

Hal ini terjadi karena beberapa dosen masih memahami paradigm mengajarsebagaitransmission of knowledge, dimanadosensebagaitransmisipemberiinformasi. Sehinggaperkuliahan yang dilaksanakanolehdosendenganmenganggapbahw amahasiswamerupakanobjekatausasaranbelajar. Suasanaperkuliahansepertiinimerupakangambara 
nperkuliahansecaramekanistik

yang menekankanpadalatihanmengerjakansoalataudril ldenganmengulangprosedursertamemberikancer amahsebagaisatu-satunyametodeperkuliahan.

Berkaitan dengan pelaksanaan perkuliahan di perguruan tinggi, dosen dituntut untuk berkerja sesuai dengan perannya di lembaga perguruan tinggi dengan lebih efektif, efesien, serta menjaga kualitas dan kuantitas kerja yang berpengaruh terhadap daya saing lembaga. Sehingga pengembangan kemampuan dosen sebagai individu yang dituntut dapat mengikuti perkembangan zaman.

MenurutKunandar untukmenghadapi era globalisasi yang penuhdenganpersaingandanketidakpastiandibutu kandosenvisionerdanmampumengelola proses belajarmengajarsecaraefektifdaninovatif.

Kemampuan dan keterampilan personil yang baik saat ini dirasakan semakin penting manfaatnya karena tuntutan atau jabatan, sebagai dampak kemajuan dari teknologi yang semakin ketat persaingannya antar organisasi/perusahaan yang sejenis.

Selanjutnya berkaitan dengan kompetensi dosen dalam melaksanakan proses perkuliahan dalam mengasuh mata kuliah, yang juga dibantu komponen lainnya yaitu sarana, prasarana dan infra struktur lainnya. Dosen menjadi faktor penting dalam kaitan pelaksanaan pembinaan, pengembangan serta pengambilan keputusan dalam rangka mewujudkan visi, misi perguruan tinggi, di samping juga dapat digunakan sebagai penilaian kinerjanya secara terbuka yang mengacu pada tridharma perguruan tinggi, sesuai dengan ketetapan Dikti bahwa.

Dosen senantiasa harus mengembangkan karya-karya inovatif dan kreatif yang dapat dicapai melalui serangkaian kegiatan penelitian maupun pengabdian kepada masyarakat yang terfokus. Sebagai konsekuensi dari profesional seorang dosen dalam bidangnya, maka dosen harus mampu mencapai tingkatan kompentensi dalam bidang ilmu yang menjadi tanggungjawabnya.

Berdasarkan hasil penelitian, terungkap juga bahwa untuk meningkatkan mutu dari perkuliahan yang dilaksanakan oleh dosen, maka dosen juga mengembangkan ilmunya, serta mengikuti perkembanganilmu pengetahuan saat ini. Upaya dosen dalam mengembangkan ilmu dapat dilakukan melalui penelitian, yang kemudian dapat dijadikan bahan diskusi dan bahan perkuliahan untuk meningkatkan kompetensi mahasiswa. Selanjutnya pada pelaksanaan perkuliahan, dosen dituntut untuk lebih banyak berinteraksi dengan siswa untuk memberikan bimbingan serta arahan bagi siswa yang mengalami kesulitan. Dosensebagai seorang pendidik berperan sebagai mediator dan fasilitator yang membantu agar proses belajar mengajar berjalan dengan baik. Oleh karena itu dosen menjadi mitra yang aktif dan merangsang pemikiran mahasiswa.

Proses mengkonstruksipengetahuan yang dialamimahasiswaperlumendapatbimbingandari dosen.

Olehkarenaitu, dosenharusmampumendesainperkuliahansedemi kianrupa,

hinggamahasiswadapatmembangunsendiripemah amannyamelaluiaktivitaskuliah yang didesainolehdosen.Kegiatan yang pentingdalamperkuliahanadalahmemberiinterpre tasimelaluiskemata yang dimilikimahasiswa.Mahasiswadiberikankesempa tanuntukmengkonstruksisendiripengetahuannya. Peran dosen sebagai pendidik dalam proses perkuliahan adalah memfasilitasi mahasiswa untuk mengkonstruksi pengetahuan yang sesuai dengan skema dan pengetahuan awalnya.

Selanjutnyapadatahapakhirperkuliahandos enmenutupkuliahdenganmembuatkesimpulan.Pe ntingnyamembuatkesimpulanpadaakhirperkuliah an,

Kegiatanmerangkumdanmenarikkesimpulandapa tdilakukanolehpesertadidik

bawahbimbingandosen/guru,

ataupesertadidikbersama

guru.Kegiatanmembuatkesimpulaniniakanmema ntapkanmateri telahdipelajariolehmahasiswa. yang

Selanjutnyadenganpertimbanganwaktu yang semuasubjekpenelitiantidakmelakukan terakhirperkuliahan tidakcukup, semestinyadibuatuntukmeyakinkandosenbahwa mahasiswatelahmencapaitingkatketuntasanbelaja r.

\section{c. Kemampuan dalam Evaluasi Perkuliahan}

Evaluasi adalah bagian tidak dapat dipisahkan dari proses belajar mengajar, evaluasi merupakan kegiatan identifikasi untuk melihat apakah suatu kegiatan yang telah direncanakan telah tercapai atau belum, berharga atau tidak, dan dapat pula untuk melihat tingkat efisiensi pelaksanaannya.

Saat ini evaluasi diarahkan bukan lagi merupakan proses akhir dari perkuliahan, namun merupakan suatu proses kontinyu untuk 
membantu mahasiswa memperoleh mencapai tujuan perkuliahan dan memperoleh kompetensi minimal.

Sehinggasetiappenilaiandiharapkanmemp unyai program tindaklanjut, yaitu program pengayaanbagimahasiswa yang telahmemenuhiketuntasanbelajar.

Berkaitan dengan kemampuan dosen dalam melaksanakan evaluasi perkuliahan merupakan kemampuan untuk mendapatkan data dan informasi yang lengkap dari proses dan hasil belajar mahasiswa, sehingga dosen dapat mengambil keputusan dan tindak lanjut yang tepat terhadap perkembangan belajar mahasiswa. Sehingga evaluasi berhubungan dengan pengambilkan keputusan oleh dosen, sebagaimana yang telah dijelaskan oleh Djamarah. Sehingga evaluasi dapat dikatakan sebagai kegiatan identifikasi untuk melihat apakah suatu kegiatan perkuliahan yang telah direncanakan telah tercapai tujuan atau belum, dan dapat pula untuk melihat tingkat efisiensi pelaksanaannya.

Berdasarkan hasil observasi penelitian terungkap bahwa, kegiatan evaluasi yang dilaksanakan oleh dosen di Sekolah Tinggi Ilmu Tarbiyah Al-Hilal Sigli merupakan upaya untuk mengumpulkan informasi hasil belajar mahasiswa, pemilihan cara dan alat yang tepat oleh dosen disesuaikan dengan karakteristik materi perkulihan dan dilakukan dengan hatihati, karena tidak semua dosen dapat mengumpulkan informasi yang tepat tentang hasil belajar mahasiswa. Selanjutnya data hasil penelitian juga menunjukkan bahwa kegiatan evaluasi perkuliahan yang dilaksanakan oleh dosen yang digunakan untuk menilai kemajuan dan keberhasilan mahasiswa di Sekolah tinggi ilmu tarbiyah Al-Hilal Sigli adalah melalui pertimbangan kemampuan menjawab soal-soal baik secara lisan maupun tulisan ujian quiz di awal semester, midterm di tengah semester dan final di akhir semester serta latihan-latihan soal dan pengerjaan tugas-tugas mandiri/kelompok.

Evaluasi yang dilaksanakan oleh dosen di Sekolah Tinggi Ilmu Tarbiyah Al-Hilal Sigli diarahkan bukan lagi merupakan proses akhir dari perkuliahan, namun merupakan suatu proses kontinue untuk membantu mahasiswa mencapai tujuan perkuliahan dan memperoleh kompetensi minimal,sehingga dapat mengetahui perkembangan peningkatan belajar mahasiswa, serta dapat diupayakan perbaikan pelaksanaan perkuliahan untuk meningkatkan pemahaman mahasiswa.
Berdasarkan hasil penelitian terungkap bahwa dosen menggunakan data dari tes ujian quis, dan ujian tengah semester (midterm exam), dan juga ujian akhir pada tiap akhir semester untuk menentukan tingkat prestasi mahasiswa dalam mengikuti perkuliahan. Selanjutnya dosen juga menganalisis hasil dari evaluasi tersebut untuk memperoleh data yang lengkap bagi dosen untuk mengambil suatu sikap terhadap proses perkuliahan selanjutnya, sebagaimana yang telah dijelaskan oleh Munthe.

Selanjutnya berdasarkan hasil penelitian juga menunjukkan bahwa dalam melaksanakan evaluasi perkuliahan, dosen menetapkan tujuan perkuliahan yang kemudian diuraikan menjadi indikator-indikator, sehingga dosen dapat menentukan tagihan kepada mahasiswa melalui instrumen penilaian baik dengan menggunakan prangkat tes tulis ataupun tes lisan. Selanjutnya dapat digambarkan bahwa kebijakan pimpinan Sekolah Tinggi Ilmu Tarbiyah Al-Hilal Sigli mendorong dosen untuk menyusun alat evaluasi dengan mempertimbangkan teknik evaluasi yang dikembangkan sesuai dengan buku pedoman akademik yang dimiliki Sekolah Tinggi Ilmu Tarbiyah Al-Hilal Sigli.

Sesuai dengan pedoman pelaksanaan evaluasi yang ada di Sekolah Tinggi Ilmu Tarbiyah Al-Hilal Sigli, dosen disarankan untuk menggunakan berbagai penilaian atau bentukbentuk penilaian lain selain penilaian tes tulis, sebagai salah satu cara untuk melengkapi data/informasi tentang perkembangan hasil belajar mahasiswa. Dosen diharapkan dapat mengembangkan sistem penilaian alternatif, hal ini senada dengan pendapat Munthe, Hal ini didasarkan pada penilaian hasil belajar mahasiswa erat hubungannya dengan penilaian terhadapproses perkuliahan itu sendiri. Sehingga dosen harus memonitor dan memantau perkembangan belajar mahasiswa pada pelaksanaan perkuliahan agar mendapatkan informasi atau data perkembangan mahasiswa.

\section{Motivasi \\ MelaksanakanPerkuliahan}

Dosendalam

Kemudian, seperti yang telah dipaparkan sebelumnya bahwa berkaitan dengan motivasi dosen dalam melaksanakan perkuliahan sangat dipengaruhi oleh faktor kemauan dan kesadaran dosen itu sendiri dalam melaksanakan perkuliahan yang efektif dan efisien, sebagaimana yang telah dijelaskan oleh Usman, Husaini. Selain itu juga dipengaruhi oleh pendapatan atau kesejahtraan, sarana/prasarana, 
dan rasa nyaman, harmonis serta suasana yang menyenangkan, sehingga para dosen tergerak untuk dapat berkerja secara optimal dalam berkerja.

Berdasarkan hasil penelitian berkaitan dengan motivasi dosen dalam melaksanakan perkuliahan sangat dipengaruhi oleh faktor kemauan dan kesadaran dosen itu sendiri dalam melaksanakan perkuliahan yang efektif dan efesien. Selain itu juga dipengaruhi oleh pendapatan atau kesejahtraan, sarana/prasarana, dan rasa nyaman, harmonis serta suasana yang menyenangkan di lingkungan kerja. Selanjutnya berkaitan dengan kesejahteraan terungkap bahwa pendapatan atau kesejahteraan mempengaruhi kinerja dosen dalam melaksanakan tugas dan kewajibannya, sehingga banyak dosen yang aktif diluar kampus, baik mengajar di universitas swasta, menjadi konsultan, aktif di LSM dan lain-lain. Sehingga dengan demikian bahwa motivasi dosen dalam melaksanakan tugas dan tanggung jawabnya, gaji dan kesejahteraan dosen sangat mempengaruhi, hal ini sesuai dengan pendapat Al-Abrasyi dalam Tafsirnya. Karena pekerjaan dosen/guru merupakan pekerjaan yang mulia dan memiliki strata sosial yang baik di masyarakat sehingga walaupun kesejahteraan saat ini belum begitu baik, kenyataannya tidak menurunkan kinerja dosen secara signifikan.

Selanjutnya faktor lain yang dapat menyeimbangkan motivasi dosen saat ini, sehingga walaupun kesejahteraan dosen belum dapat dikatakan baik, namun iklim yang kondusif dapat meningkatkan motivasi dosen dalam bekerja. Hasil penelitian, menunjukkan bahwa berkitan dengan motivasi dosen dalam meningkatkan kinerja dosen, berdasarkan hasil penelitian menunjukkan bahwa keadaan yang kurang nyaman di lingkungan Sekolah tinggi ilmu tarbiyah Al-Hilal Sigli dapat membuat motivasi kerja dosen menurun, karena dosen merasa tidak nyaman dan tenang berada di kampus, sehingga hubungan muncul kondisi yang kurang bersahabat dan kurang adanya kekeluargaan yang nampak diantara warga kampus, mulai dari pimpinan Sekolah Tinggi Ilmu Tarbiyah Al-Hilal Sigli, dosen, mahasiswa maupun para pegawai administrasi.

Iklim perguruan tinggi yang yang kondusif seperti pengaturan lingkungan, hubungan yang harmonis antara mahasiswa dengan dosen dan di antara para mahasiswa itu sendiri, serta penataan organisasi dan bahan perkuliahan secara tepat, sesuai dengan kemampuan dan perkembangan mahasiswa ini sudah relatif baik. sehingga iklim yang menyenangkan seperti ini dapat membangkitkan semangat dan menumbuhkan motivasi serta membangkitkan kinerja dosen pada Sekolah tinggi ilmu tarbiyah Al-Hilal Sigli. Adanya faktor lain yang dapat menyeimbangkan motivasi dosen saat ini, sehingga walaupun kesejahteraan dosen belum dapat dikatakan baik, namun iklim yang kondusif dapat meningkatkan motivasi dosen dalam bekerja.

\section{Kesimpulan}

Berdasarkan hasil penelitian yang telah disajikan pada bab IV, maka dapat diambil beberapa kesimpulan sebagai berikut:

1. Kinerja dosen dalam melaksanakan proses perkuliahantelahmengikutiprinsip-

prinsippembelajaran, halinidilihat dariperencanaan perkuliahan yang dibuat oleh dosen.Selanjutnya pelaksanaan perkuliahanmengacu pada SatuanAcaraPerkuliahan (SAP) yang telah disusun dan memperhatikan kesesuaian antara materi, strategi, dan metode yang digunakan, serta evaluasi perkuliahan dilaksanakan oleh dosen secaraterstruktur melalui tessecara lisan maupun tulisan, baikdalamujian quizs di awal semester, midterm (UTS) dan ujian final di akhir semester.

2. Kemampuan dosen dalam melaksanakan evaluasi perkuliahan merupakan kemampuan untuk mendapatkan data dan informasi yang lengkap dari proses perkuliahan yang telah dilaksanakan oleh dosen sampai akhir, hal ini adalah kegiatan untuk mengetahui sejauhmana mahasiswa dapat menyerap dan memahami materi perkuliahan dengan baik, serta dosen juga akan mendapatkan informasi terhadap kesulitan dan kendala mahasiswa pada proses perkuliahan, sehingga dapat diambil keputusan dan tindak lanjut yang tepat untuk meningkatkan pemahaman mahasiswa.

3. Motivasi dosen dalam melaksanakan perkuliahan tercermin pada kemauan dan kesadaran dosen dalam melaksakan tugastugas yang diembankan kepadanya, seperti sangat termotivasi dalam melaksanakan proses perkuliahan, disamping itu ada beberapa dosen yang sedang melanjutkan pendidikan kejenjang yang lebih tinggi, dan terjalinnya hubungan yang harmonis, antara pimpinan Sekolah Tinggi Ilmu Tarbiyah 
dengan dosen serta staf karyawan lainnya. Sehinggamenjadikanpara dosen termotivasi untuk berprestasi dengan baik dan melahirkan kepuasan dalam bekerja.

4. Motivasi dosen terhadap tugas, pimpinan Sekolah Tinggi Ilmu Tarbiyah Al-Hilal Sigli telah berupaya dengan memberikan penghargaan, kepada dosen berprestasi dalam melaksanakan tugas sesuai dengan bidangnya masing-masing. Pihak pimpinan Sekolah Tinggi Ilmu Tarbiyah Al-Hilal telah mengambil kebijakan dengan menaikkan honor mengajar dosen dan memberikan penghargaan atau honor tambahan bagi dosen.

5. Motivasi dosen dalam melaksanakan proses perkuliahan, berdasarkan temuan penelitian menunjukkan bahwa keadaan yang kondusif di lingkungan kerja dapat membuat motivasi kerja dosen meningkat, karena dosen merasa nyaman dan tenang berada di kampus, hubungan kekeluargaan sangat perlu dibangun sehingga nampak bersahabat dan harmonis diantara warga kampus, mulai dari pimpinan Sekolah Tinggi Ilmu Tarbiyah AlHilal, dosen, mahasiswa, para karyawan dan pesuruh kantor. Keadaan semacam ini menyebabkan dosen merasa aman, tentram, bebas dari segala tekanan yang bisa merugikan kegiatan perkuliahan.

\section{DAFTAR PUSTAKA}

Catherine Dawson, MetodologiPenelitianPraktis, Yogyakarta: PustakaPelajar, 2001.

Iskandar,

MetodelogiPenelitianPendidikandanSosi al (Kualitatif dan Kuantitatif),Jakarta, GP Press. 2009.
Mulyasa, Standar Kompetensi Dan Sertifikasi Guru. Bandung: PT. Remaja Rosdakarya, 2009.

PresindenRepublik Indonesia UndangUndangNomor 14 2005, tentang GurudanDosen. Jakarta: SinarGrafika, 2005.

Sanjaya, Wina, Perencanaan dan Desain Sistem Pembelajran, Jakarta: Kencana, 2010.

Sugiyono, Metode Penelitian Pendidikan (Pendekatan Kuantitatif, Kualitatif, dan R\&D),Bandung, Alfabeta. 2009.

Usman Nasir, ManajemenPeningkatanMutuKinerja Guru, Konsep, Tiori dan Model, Bandung: Citapustaka Media Perintis, 2012. 